\title{
ROBERT WESSING
}

\section{Dislodged tales \\ Javanese goddesses and spirits on the silver screen}

\section{Introduction}

Indonesian films and television shows often feature popularly though only superficially known figures from Javanese mythology, including the Goddess of the Southern Ocean Nyai Roro Kidul and her counterpart the Queen of the Snakes Nyi Blorong. ${ }^{1}$ In this study I examine the effects of placing the stories about these entities in 'media space' (Sen and Hill 2000:199), thus removing them from the local context that in the past infused them with its truth, ${ }^{2}$ and making possible their apposition to other truths and values that were previously unconnected to them, and may or may not be congenial with them. Starting with a short discussion of the nature of stories and their relationship to locally perceived truths, I briefly look at some defining features of the mythological characters Nyai Roro Kidul and Nyi Blorong and how these, as well as references to other mythologies, are used in films. I then consider how through the agency of various supporting roles social and moral judgments are made on events in the film (and implicitly in society). The context of the viewing, for example theatre versus television, is an important factor that influences the reception of the film's message; as the films remove our characters from a local, intimate immediacy they in the process gain a voice in a debate concerning the place of these mythological figures and the beliefs

1 I would like to thank the Maatschappij voor Wetenschappelijk Onderzoek in de Tropen (Treub-Maatschappij) for their support of the research on which this article is based. I also thank Randal Baier, John Emigh and Sean Williams for their insightful comments, and the Dutch painter Frans Erkelens for permission to use his painting of Nyi Blorong. For details about him and his work see http://www.franserkelens.nl/ (accessed 21-9-2006).

2 I use the word truth here in the sense of something self-evident to the people involved that underlies their perceptions of their lives and social situation. This would include the accepted, if sometimes mythological, accounts of the nature and origin of their physical and social worlds, and the social order claimed to be based on or justified by such accounts. It includes people's relations with entities in the 'supernatural' realm, as well as who in the community is empowered to deal with these. Such perceptions may, of course, vary and may be challenged by others in the community.

ROBERT WESSING, who holds a PhD from the University of Illinois, Urbana, has specialized in anthropology. He is the author of The soul of ambiguity; The tiger in Southeast Asia, DeKalb: Center for Southeast Asian Studies, and 'Telling the landscape; Place and meaning in Sunda (West Java)', Moussons 4, 2001, pp. 33-61. Dr Wessing may be contacted at robertwessing@yahoo.com. 
associated with them in a modern Indonesia where a variety of Islamic voices increasingly clamour to be heard.

In spite of the increasing influence of Islam in daily life in Java, mythological themes and ideas about magical powers remain important (Fish n.d.; Wessing 2006a). These ideas find expression in beliefs about spirits and supernatural forces, both local and supra-local, even though there is an ongoing discussion between various adherents of Islam and proponents of modernity about how these phenomena should be regarded (Wessing 2002). The degree to which these matters are part of people's daily reality can be seen in the popularity of ghost-reality shows on television in Java (Arps and Van Heeren 2006) and people's almost routine, if sometimes anxious, day-today involvement with spirit entities (Fish n.d.; Wessing 2006b).

This obvious presence of spirit beliefs should not lead us to believe that there is unanimity about either their reality or, among those to whom they are real, about how to value them. Some dismiss most Javanese spirits out of hand, calling these beliefs old-fashioned, though perhaps retaining a belief in Islamically sanctioned ones like jin (genies). Others acknowledge the reality of the spirit pantheon (Wessing 2006a), but disagree about whether at least some of these entities are benign or if they should all be classified as setan (devils), interaction with which is dangerous and perhaps idolatrous (syirik). However, believer or not, most everyone is aware of the social fact of the phenomenon, which is part of the 'story', in the sense of Fisher (1987), Niles (1999), and Bruner (2002), through which people in Java constitute their social reality.

\section{Narration}

Fisher (1987:xi) and Niles (1999:3, 8) see humankind as tellers of tales, Homo narrans, who constitute their communities and realities through the stories they tell, participation in which differentiates the insider from the outsider (Wessing 2001; see also Bruner 2002:16). Mutual participation in these tales and the premises that underlie them causes the realities envisioned ${ }^{3}$ in the tales to be realized performatively, in the sense of Austin (1975). However, as Bruner (2002:91) mentions, there are many stories and not everyone in a community needs to agree with any one of them, with every detail of the ones they do agree with, or about the veracity of particular versions. This leads to discussion and, ideally, to attempts at compromise, though it can also lead to schisms and discontent. Usually, however, people will mute their disagreements (Beatty 1996; Wessing 2002). It is, furthermore, not necessary for every

3 Envisioned in the sense of Anderson (1991): a mental construction that may, under the right circumstances, lead to a physical or social reality. Fisher (1987) and Niles (1999) use narration in the broadest sense, including myths, history, and personal descriptions and the like (see also Turner 1981:153). 
member of the community to know the tales in detail or be able to tell them with great accuracy. This is within the purview of a small number of people, the local experts to whom the community as a whole defers (Niles 1999:175).

Truth, then, is a matter of social agreement, and the acceptability or 'truth' of a myth or legend can vary with changes in the social context of its telling. ${ }^{4}$ Thus, 'truth' here is seen as a social fact that is continually judged against other truths by the participants in the discussion (Wessing 1978b; Bruner 2002:91; Hobart 1999:281). As I have pointed out elsewhere (Wessing 2001), such a judgment, and thus also the reality it defines, is usually a quite local matter, involving known people and local icons that come together to create a reality that in turn defines the people's and icons' actuality. Of course, the scope of this localness must vary with the general applicability of the tale in question. Since adherence to a particular version defines an in-group, the acknowledged teller of a socially important tale becomes a person of consequence in the community it defines: he or she is one who structures reality (Niles 1999:3, 212 note 48 ), and where different tales or different versions define significantly different realities, social relationships may well be altered (Niles 1999:87; Wessing 2002; Nourse 1999:175, 191), while the tales themselves can become arenas for political competition between competing experts. ${ }^{5}$

As is clear from Nourse's work (1999), the acceptance of versions of stories that are especially important to a community often depends on who the dominant voice among these experts is. The role of the audience is vitally important here, as acceptance of the narration depends on it. As Hobart observes, social life is essentially dialogic, and without an audience a speaker is just talking, without the social validation that brings his or her tale into the realm of truth. ${ }^{6}$ Yet the audience is a heterogeneous assemblage that is conditioned by previous beliefs as well as the relative and changeable politi$\mathrm{cal} /$ power positions occupied by the narrator and the individuals making up the audience (Bruner 2002:64, 66; Spitulnik 1993:297). This is, of course, more generally true than just in the area of mythological recitation and can be applied to all statements and social actions. ${ }^{\text {? }}$

4 Wessing 2006b; Bruner 2002:58; Hobart 2002:380. The truth of a myth or legend need not be factual (Niles 1999:133). Rather, these are stories 'which people may infuse with their truth' (O'Flaherty 1988:35).

5 When doing field research in 2004 among East Javanese teenagers on their knowledge of mythology, my interviews in one locality were often disturbed by an older self-appointed expert, who due to the superiority conferred by his (middle) age would effectively silence my informants who then deferred to him.

6 Niles 1999:61; see also Fish n.d. This seems to be especially true in, among others, Balinese theatre, where interaction with the audience is a vital aspect of the production (Emigh 1996; Hobart 2002:377, 380-1; see also Tuti Indra Malaon 1988:13).

7 Elsewhere (Wessing 1978b:173) I note that everyone is simultaneously actor and audience, judging the actions of others as to their acceptability and simultaneously having their own actions judged through the reactions of others. 
In the view presented here, then, communities come about as a result of the interaction between the various narrations of tales presented by its members: the community talks itself together. Some of these tales carry more weight than others, depending on the position of the narrator within the group, and both the tales and the position of the narrator can change over time as they adapt to changing circumstances (Bruner 2002:58; Nourse 1999:175-91): future generations may have to reinterpret or reconstruct the 'truth'. Furthermore, although communities are based on shared 'truths', these need not be based on objective reality. Rumours about something that has happened or fears about something that might happen are equally effective in binding people together for shorter or longer periods of time (Spyer 2002).

Although the literature about narration seems to focus primarily on regional or national communities, the above observations apply equally to local communities, especially since national or regional tales are also told or referred to locally. This tends to link wider concerns with local realities, but can also place local matters in the context of a broader discussion (Wessing 2001, 2002b). Thus, while the Javanese goddesses and other figures we will be looking at here used to be primarily matters of local concern (Wessing 2006b), since their film debuts they have progressively become caught up in a larger discussion about Indonesia, modernity and Islam and their position vis-à-vis these mythological entities. This is increasingly apparent in television films about them, where their portrayal can vary from absolute evil, to neutral, to benign and advisory. Before going into these portrayals, however, I will first present the mythological figures in brief outline.

\section{The characters}

Nyai Roro Kidul, a figure well known in the literature on Java, ${ }^{8}$ has become more widely known among the people of Java since the film debuts of her and her 'daughter' Nyi Blorong. Especially since the 1982 film Nyi Blorong (Putri Nyi Roro Kidul), she and Nyi Blorong have gained broader popularity and name recognition. Prior to this Nyi Blorong was relatively unknown. Now she is mainly recognized as the Queen's daughter and ruler of the snakes, but even with this recognition detailed knowledge about either is rare among the general public (Wessing 2006b:53).

Nyai Roro Kidul, Queen of the Southern Ocean, is actually part of two separate traditions, one relevant to Java's courts and the other to the fishermen on the island's southern coast. In the first, part of a Southeast Asia-wide tradition of liaisons between rulers and naga princesses, she is a guardian spirit (dhemit) responsible for the welfare of Java, having entered a relation-

8 For detailed references, see Wessing 1997b, 2006b. 
ship with the founder of the Muslim state of Mataram, Panembahan Senopati (Wessing 1997b). While this court tradition is often retold in collections of folk tales (for example, Terada 1994:143), it has not been portrayed in any of the films about her that I have seen. ${ }^{9}$ In these printed stories the queen is a beautiful princess ${ }^{10}$ who, in some tales due to a foul-smelling skin disease, came to be banished from the palace. Wandering through the forests of Java, she came to the Indian (Southern) Ocean, where she heard a voice telling her to enter the waters and be cured. Having done so she became the ruler of the spirits of Java, living in a sumptuous underwater palace (Jordaan 1984; Nyai Roro Kidul 1991:130). While there is some dispute about this matter (Schlehe 1998:144), mermaid-like, her lower body today is reputedly covered with scales, which can refer either to her marine habitat or her association with mythical snakes (naga) (Har n.d.:36; Harnaeni Hamdan Hs. n.d.:16). Indeed, Jordaan's informants referred to the Queen as a naga and her (flying) carriage is decorated with a naga motif (see Plate 1), a motif also found in related mythology (Jordaan 1984:108-9).

Among fishermen on Java's south coast, a quite different tradition about the Queen is current. The court tradition generally goes unmentioned there, except in the Parang Tritis/Parang Kusuma area of Central Java, where annual offerings are made to the Queen by the court and where she reputedly met Panembahan Senopati. Along most of the coast, where her origins are not discussed as such, she is considered the ruler of the ocean and the controller of its wealth ${ }^{11}$ as well as one who punishes disorderly behaviour. Fishermen's catches are said to depend on her goodwill, and she is reputed to demand offerings of human lives in return for her beneficence (Wessing 1997a). She is the ruler of the spirits of Java and she is easily angered, especially by those who dare to wear her favourite colour, green, to the beach. Such persons are apt to be swept away by a large wave to henceforth serve her in her underwater palace and, if they are handsome young men, to satisfy her considerable sexual appetite. Her daughter is also attracted to handsome young men and, like her 'mother' with Senopati, may dally with them under water for several

9 There have been plans for a television special about the meeting between Nyai Roro Kidul and the ruler of Mataram (TVRI Yogyakarta 1991:5).

10 In the Penembahan Senopati tale, the queen is usually portrayed as both beautiful and sexually attractive. Senopati is said to have spent three days and nights making love with her (Olthof 1987:80-2). Nyai Roro Kidul is usually portrayed as a beautiful young woman. It is said, though, that she changes with the phases of the moon, appearing young and beautiful when it waxes but old and ugly when it wanes (Sri Sultan 1988:156). This may be the basis for the description of her in the Babad Demak (History of Demak) (Sabariyanto 1981:44), where she is said to have an enormous body with thick hair and tusk-like teeth, three hand-spans long. Her breasts are enormous and she snores loudly in her sleep. When Senopati saw her real form, the Babad continues, 'he was sore afraid'.

11 She is also the protectress of the harvesters of swallows' nests on the steep southern cliffs (Air liur 1982:75-6; Knappert 1977:72-4). 
days, returning them to the shore afterwards, now able to effect cures. ${ }^{12}$

Children's books are generally about the Queen's relationship with fishing communities. ${ }^{13}$ The films about her or Nyi Blorong refer either to coastal communities or are set in urban areas. Most of my informants in East Java were unaware of the court connection, unlike those living in Yogyakarta and in Parang Tritis and Parang Kusuma, all in Central Java, who, being near the court and its ritual centres, were aware of the connection. As Headley (2004:138) points out, probably referring to the Central Javanese court tradition, her 'cult hardly extends beyond the palaces and a number of villages on the southern coast'. The court and coastal traditions, then, tend to address different interests, the one being concerned with legitimating Senopati's rule and the founding of Mataram, while the other has to do with the risks of making a living from the dangerous waters of the Indian Ocean. In children's books and films depicting the coastal tradition, Nyai Roro Kidul is often dressed in some archetypal 'court dress', befitting her status as queen.

\section{Nyi Blorong}

Until the actress Suzzanna ${ }^{14}$ portrayed her in 1982, Nyi Blorong was a relatively obscure figure. She is said to be a beautiful woman (Schlehe 1998:240) who, like Nyai Roro Kidul, can appear as a woman with a fathom-long snake's tail covered with jewels or golden scales (see Plate 2). ${ }^{15}$ She is a money goddess who lives in still waters or swamps, though according to Meijboom-Italiaander (1924:235) she lives in a palace in the Indian Ocean. If properly appeased, she is said to bring one untold riches in return for which the supplicant, generally a man, must be prepared to copulate with her every thirty-five days at the Jum'at-Kliwon conjunction of the Javanese seven- and five-day weeks. This wealth, however, turns out to be as ephemeral as the sexual satisfaction, and after seven years the beneficiary must pay by being physically made part of her palace. ${ }^{16}$ Since the 1982 film, Nyi Blorong is popularly said to be Nyai Roro

12 Bamar Eska n.d.:58. Subiyanto Hr. (n.d.:50) writes that the Queen has three daughters and two sons, all unnamed, whose fathers are unknown. All five engage in free love with both men and women.

13 Harnaeni HHs 1985, 1985b, n.d.; Rully n.d. The only exception is a rather deviant one by Harnaeni Hamdan.Hs. (n.d.).

14 For the actress Suzzanna, see http://mitglied.lycos.de/uzumaki/specials/suzzanna.htm (accessed 21-7-2006).

15 Kreemer 1879:6, 9 note 4) Elsewhere this figure is the male Kiai Blorong or Belorong, who has a shark's tail as lower body (Knappert 1977:75).

16 Van Hien 1912:145; see the skulls in the illustration in Kreemer 1879:facing p. 1. In the case of the Sundanese ipri (Wessing 1988:54; Rosidi 1977:95-105), whom Nyi Blorong closely resembles, this fate can be postponed if the supplicant brings her other human sacrifices. Wormser (1920) attributes the suffering-for-wealth aspect to Nyai Roro Kidul. 
Kidul's daughter but, as Schlehe (1998:143) points out, in older mythologies she is said to be the offspring of Raja Angin-angin, the ruler of the spirit world who preceded Nyai Roro Kidul.

In summary, in both the court and the coastal traditions Nyai Roro Kidul is associated with underworld elements like fish and snakes (naga). In the court tradition she originated as a princess who entered the ocean to be cured of a skin disease, while in the coastal tradition her origins are unknown. In both she is the Queen of an underwater realm who enjoys an active sex life: in the court tradition with Panembahan Senopati and his heirs, whose liaisons with her legitimates their power, and in the coastal tradition just to satisfy her lust and to add to her palace staff in exchange for good catches. Nyi Blorong shares with the Queen the association with snakes and sexual license, though Nyi Blorong exchanges it for personal wealth rather than for political power or general welfare. Nyi Blorong makes her supplicants physically part of her palace rather than using them as servants or lovers. All these elements are exploited in the films, to which I now turn.

\section{Screen goddesses}

The films we will be looking at can, with one possible exception, be placed in two categories: the ones made for the theatre, in which Nyai Roro Kidul or Nyi Blorong play essential and active roles in the story, and those made for television, in which they are relatively passive background figures who occasionally exercise a deus ex machina function. The possible exception is the 2003 film Anugerah Nyi Roro Kidul, ${ }^{17}$ which like the television films is more a family drama featuring the Queen than a film in which she plays an active role. In the films made for television, Nyai Roro Kidul and Nyi Blorong are usually surrounded by attendants and dressed in rather stereotyped zaman dahulu ('olden' times) ${ }^{18}$ costume, which is popularly associated with the times of the courts and Javanese kingdoms. Their costume therefore invokes the past and royalty (see Plate 3 ). In theatre-release films their costume tends to vary between 'court' dress, ordinary street clothes where relevant (for example, in Bangunnya Nyai Roro Kidul), and a green gown, a reference to a painting by Basuki Abdullah (Schlehe 1998:plate 24), which at one point in Pembalasan Ratu Laut Selatan is an integral part of the film.

The association with snakes is made abundantly clear in most of the films. In Nyi Blorong (Putri Nyi Roro Kidul) Nyi Blorong hatches from a naga egg, and snakes writhe Medusa-like on her head in Petualangan Cinta Nyi Blorong (see

17 When available, the release date and details about the cast and the like for the films discussed here can be found on the websites mentioned in the list of films.

18 I am indebted to Dr Ratna Saptari for this characterization. 
Plate 4). In both films she travels in a flying naga carriage, similar to the one used by the Queen in Plate 1. A similar carriage also appears in the made-fortelevision Nyai Roro Kidul that I viewed in 2004. Although neither has much of a role in the episodes made for television, where they act primarily as sage observers who interestedly keep track of the human protagonists (Misteri Dua Alam: Mustika Nyi Roro Kidul, Indosiar 17 April 2006), when they do appear, snakes and snake symbolism are abundantly present. Nyai Roro Kidul rides in a naga carriage, while in Mustika Nyi Roro Kidul she is said to be an incarnation of a cobra (ular sendok). A very large snake emerges from her hand when she engages in silat combat (Indosiar 17 April 2006), which in Misteri Dua Alam: Anak Titipan Nyi Blorong (Indosiar 27 March 2006) also happens to Nyi Blorong's son, the result of one of her affairs.

In the myths as recounted above, the sexual aspect of the two figures plays a relatively important, though not dominant part. The Queen trysts with Panembahan Senopati, in the process giving him power over his future realm (Wessing 1997b:330-2), and in the coastal tradition she desires young men as lovers. Nyi Blorong demands sexual satisfaction from men in return for wealth. In the films this aspect is exploited to the degree that Pembalasan Ratu Laut Selatan was temporarily forbidden by the censors, which only added to its allure. ${ }^{19}$ Such publicity draws attention to the films, making them especially attractive to the teenage audiences that, according to Heider (1991:20-1), come to see these films. ${ }^{20}$

Finally, there is the Queen's insistence that on the beach she is the only one allowed to wear green -- a monopoly that she occasionally shares with Nyi Blorong, who in the television film Nyi Blorong; Titisan Ratu Nagandini (1 April 2006) appears as a green snake. So jealous is she of this prerogative that in Kutukan Nyai Roro Kidul she kills a painter who not only wears a green T-shirt to the beach, but also has the temerity to use his girlfriend as a model for the Queen, wearing a green dress in the painting. Even when in ordinary street clothes, as in Pembalasan Ratu Laut Selatan, the Queen is recognizable by an obvious piece of green clothing. When shooting Kisah cinta Nyi Blorong, the star Joice Erna established spiritual contact with the Queen to ask per-

19 A newspaper advertisement for Ajian Ratu Laut Kidul used the words terberani (most daring), erotisme (eroticism) and permainan asmara (love play).

20 Schlehe 1991:206. Heider (1991:20-1) observes that the majority of theatre-goers are boys between 15 and 24 years of age, a segment of the population that with a total of 40,400,000 made up about 20\% of Indonesia's population in 2000 (Zimmermann 2003:553). It is also the age group that, with its awakening sexuality, would be drawn by the sometimes not so implicit sexual activity portrayed in the films. Legenda (1988:1) characterizes the theatre audiences for Nyai Roro Kidul films as consisting of 'pedicab drivers, maids, drivers and gardeners', these myths being 'consumed by the lower classes, villagers, or officials and elite people who came from villages' (see also Sen and Hill 2000:154). The middle-class teenagers I interviewed in 2004 had all seen most of the films made about her, primarily on television. 
mission both to portray her daughter and to wear green. ${ }^{21}$ This seems to have been neglected by the actress Ully Sigar Rusady, who, wearing green on the beach while shooting near Pelabuhan Ratu, got more than she bargained for when she urged the Queen to hurry up and send a large wave: an enormous swell suddenly approached that washed her into the rocks (Diam-diam 1989). So firmly do people believe in her monopoly on this colour that I have never seen a Javanese wearing green on the Indian Ocean beach in East or Central Java, and, when the film Ajian Ratu Laut Kidul was playing in Jember (East Java) in 1991, it was cautioned that if one wore green to the theatre, Nyai Roro Kidul would possess the wearer.

Summarizing, we see that the films exploit the symbolic association of the Queen and Nyi Blorong with the colour green, snakes and sexual license, especially the latter, giving viewing the films a cachet of naughty or even sinful entertainment. As we have seen, the details of the two mythologies also tend to spill over into each other, in the films and the literature alike. Thus Purbatjaraka (1962, I:20) has people petitioning the Queen for wealth and paying the same price that Nyi Blorong usually exacts (Van Hien 1912:173). As Jordaan observes, 'the parallels are striking'. Whether or not the two mythologies were always related in this way (Jordaan 1984:109; Schlehe 1998:144) does not matter: Nyai Roro Kidul now has a daughter. ${ }^{22}$

\section{Intertextual references}

Aside from referring to mythical elements inherent in the tales themselves, the films also bring in elements from other mythical traditions. In Petualangan cinta Nyi Blorong, for instance, a nail pounded into Nyi Blorong's head ensures that she will remain a snake and be unable to change back into her real self, a pretty girl. When the nail is removed, she immediately returns to her old self. This idea of spiking a spirit to render it impotent derives from beliefs about the sundel bolong or kuntilanak, ${ }^{23}$ which was featured in the 2004 Malaysian film Kuntilanak; Harum sundal malam and is known throughout the Malay world and into the Philippines. ${ }^{24}$ It is the ghost of a woman who died in childbirth and is

21 Pokok E tokoh 1989. Joice Erna is not alone in asking for permission to portray the Queen or her daughter. Offerings are made and permission is asked in the Queen's room (\#308) in the Pelabuhan Ratu Hotel (Uchrowi et al. 1988). The actress Suzzanna, moreover, is reputed to practise Javanese mysticism daily, making her the best candidate to portray Nyi Blorong (Film-film horor 2003:70).

22 Pokok E tokoh 1989. Fish's informants were not concerned whether the story as presented in the media was accurate. What mattered to them was the story as such (Fish n.d.:2). A concern with such authenticity or originality may well be an academic burden.

23 Also sundal bolong and kuntianak or puntianak. In Flores it is known as logo lia (Forth 1998:88).

24 Skeat 1972:329; Endicott 1970:60, 62, 81; Sell 1955:70-2; Wilken 1912:319. 
especially dangerous to women giving birth. She has disordered hair, a mutilated face, and a hole (bolong) in her back (Wessing 1978a:105; Eringa 1984:429; Prawirasuganda 1964:14). Metal objects, knives, or swords and lances are used as protection against her malign influence (Sell 1955:121), while in Flores a spike is inserted into her head to render her harmless (Forth 1998:88).

Another intertextual reference, which reinforces the connection with both sex and snakes, is to the story of Ken Dedes, the legendary founding queen of the royal house of Singhasari. It was said of Ken Dedes that she had a luminous or flaming vulva and that the man who could possess her would become a universal ruler (Brandes 1920:59). Sometimes she is said to be Nyai Roro Kidul (Wachtel 1977:19-20; Rully NH n.d.). This idea of a woman's vulva as the locus of power and danger ${ }^{25}$ became the prototype for vulvas that house a poisonous snake, endangering prospective suitors: a poisonous snake inhabits the woman's vulva and kills her husband on their wedding night, and only the man who, for example through meditation, manages to control his sexual urges can possess her in the end. In one tale the snake emerges and, caught by the famous Muslim saint Sunan Kali Jaga, turns into a keris, a ritual dagger (Prawirasuganda 1964:85-6). In Kutukan Nyai Roro Kidul the role of the Sunan is taken by an ustadz, a religious teacher, who marries a woman whose vulva the Queen has infested with a snake and several of whose husbands perished on their wedding night. He then refrains from consummating his marriage for forty days. Impatient, the snake finally appears, is caught, and the woman is healed.

In Pembalasan Ratu Laut Selatan the Queen, here cast as an evil character, kills men by copulating with them, in the process of which the snake residing in her vulva bites off their penises. One man catches the snake, however, and it turns into a keris, which eventually kills the Queen herself. In Ajian Ratu Laut Selatan, on the other hand, the snake placed within the female protagonist by the Queen is a weapon with which the woman defeats the truly evil village head and his henchmen. When it shows itself, the snake appears from above her belt rather than during sexual activity. In Kisah cinta Nyi Blorong the risque location of the snake is only hinted at when it appears from underneath Nyi Blorong's sarong, although it also appears from her mouth.

A last external reference is to shape shifting, because both Nyai Roro Kidul and Nyi Blorong can switch between being beautiful women and being snakes. While under certain socially controlled conditions shape shifting may be valued, for example when done by a curer or a shaman, it is generally associated with socially uncontrolled, dangerous magic and evil intentions (Wessing 1986:115-6) and is frowned upon, especially in more strict Muslim circles that

25 Dr. Sean Williams (email 21-8-2006) suggests a connection with the idea of the vagina dentata, which seems to be a male fear in many parts of the world (compare http://en.wikipedia.org/wiki/ Vagina_dentata (accessed 22-8-2006); Lévi-Strauss 1970:113). 
tend to disapprove of things mystical. ${ }^{26}$ Shape shifting, with its inherent uncertainty as to which one is dealing with, thus lends an extra aura of danger and dubiousness to general perception of both the Queen and Nyi Blorong.

\section{Cops, clowns, and preachers}

Not part of the original mythology, but usually present in the film versions, are elements like policemen, clowns, and religious leaders. Even though, as Sen and Hill (2000:142) write, Indonesian films are not supposed to put the police in a bad light, an informant pointed out that the tendency in these films is to have the cops arrive, often in excessive numbers (Bangunnya Nyi Roro Kidul), when the action is over and the criminals have been neutralized. An exception is Santet 2: Wanita harimau, in which the police manage to round up a gang of smugglers, but even there the worst offender is dealt with in the end by the film's female protagonist. Village government, too, is often portrayed as weak and unable to oppose the criminals, which may reflect reality, as an informant pointed out. 'In real life', he said, 'the village head is often afraid of preman (thugs), as opposing them could get one killed' (Rozaki 2004).

If we can see this as a 'comment on contemporary Indonesia' (Sen 1988:1), the clowning in these films of the late H. Bokir ${ }^{27}$ and his sidekick Dorman are statements about good intentions and human frailty. Bokir's position reflects that of the clowns in shadow-puppet presentations (wayang) in that he appeals to 'subordinate elements [...] servants, children, women' ${ }^{28}$ Bokir generally plays out a sub-plot in the film, portraying for instance a phony sorcerer without real powers, ${ }^{29}$ a bumbling guard in a house of prostitution, or a village watchman (hansip) who is as afraid as anyone of the forces he is supposed to guard against. ${ }^{30} \mathrm{He}$ has a roving eye for the ladies, ${ }^{31}$ a healthy fear of ghosts, $^{32}$ easily jumps to the wrong conclusion, ${ }^{33}$ but comments on social justice and quits his job as a guard when a criminal becomes village head. ${ }^{34}$ Like the

26 See the films Mistik (Leak), Buaya Putih, Santet: Ilmu Pelebur Nyawa, Santet 2: Wanita Harimau, Siluman Manusia Harimau (Misteri Gunung Merapi), Anita (Ular Betina), Tumbal Darah Perempuan, and Bayi Misteri, in all of which shape shifting is depicted as anti-social and evil. In the television series Legenda Ular Putih, to the contrary, the shape-shifting snake-woman opposes an evil sorcerer, and together with her human sweetheart stands for righteousness.

27 http://www.kompas.com/kompas-cetak/0210/19/dikbud/seni09.htm (accessed 20-7-2006).

28 Anderson 1990:167. Audiences watching showings of VCDs of these films would shush each other, saying, 'nih, nih Bokir datang' (here, here comes Bokir).

29 Nyi Blorong (Putri Nyi Roro Kidul); Petualangan Cinta Nyi Blorong. This theme is repeated by another actor in Bangunnya Nyi Roro Kidul.

30 Sundel Bolong, Santet: Ilmu Pelebur Nyawa, Santet 2: Wanita Harimau; Ratu Buaya Putih.

31 Santet: Ilmu Pelebur Nyawa; Santet 2:Wanita Harimau, Kisah Cinta Nyi Blorong.

32 Santet: Ilmu Pelebur Nyawa.

33 Santet 2: Wanita Harimau.

34 Santet: Ilmu Pelebur Nyawa, Malam Satu Suro. 
clowns in wayang presentations sometimes do (Sears 1996:272), he delivers government messages about people's civic duties and conservation. ${ }^{35}$ Bokir represents the common man, the anti-hero, who is as much at sea when faced with the real world as any member of the audience. He is part of the film but, like the audience, can only stand by and watch the main drama unfold. ${ }^{36}$

For all his foibles and bumbling, however, Bokir stands for order in the face of the disorder brought about within the film's tale, a position also taken by another common character, the religious teacher (ustadz) or preacher (kiai), with whom we arrive at a major arena of discussion in which these films take part. If Bokir comments on the story line and on the position of the common man in Indonesia today, these spiritual figures are part of a nation-wide debate about the nature and future of Indonesian society. This debate is carried on between the side of Islamic modernization and those who, actively or passively, continue to participate in what the modernizers of religion at best label as superstition and at worst as syirik (idolatry). As noted earlier, belief in all kinds of supernatural beings and their powers for good or ill is still very common. So too is the fear of sorcery, which many believe to be still widely practised, ${ }^{37}$ a belief that is reflected in the films as well. Tempo observes that the religious figure is imposed on these films by the Board of Film Censorship (Badan Sensor Film), an 'ultra-nationalist gatekeeper of Indonesian culture' (Sen and Hill 2000:138), according to which, though Heider (1994:167) disagrees, these kinds of films are supposed to have a religious mission (Film-film horor 2003:72). However, although this policy fits in with the greater freedom to express religious points of view in the post-Soeharto era, it cannot be said that the films as a whole have shown a greater religious emphasis since then.

Indeed, the depiction of our two mythological figures in the films is remarkably balanced. In fact, a teenage informant complained that portrayals of the Queen tend to be too tame, making the films less attractive to his age group, who prefer films that are serem (terrifying). In Ajian Ratu Laut Kidul (1991) and Bangunnya Nyi Roro Kidul (1985), both starring Suzzanna and made during Soeharto's New Order regime, the Queen is depicted as supporting the forces of order and foiling nasty schemes, though in the latter film she does engage in some (implied) explosive underwater sex with the leading man. As

\section{Santet 2: Wanita Harimau}

36 Anderson 1990:167; Foley 1992:27. As such he resembles the penasar cenikan of Balinese masked theatre, described by Emigh (1996:134), in that in playing 'across that gap' between the film and the audience, he makes 'the telling of the story [...] more recognizably human'. If in Balinese theatre the gap to be bridged is between the past and the present, in these films it is one created by the fact that, unlike in live theatre, the audience is not physically present at the performance, but is a step removed into the anonymity of a movie theatre. On the challenges faced by Balinese performers when their audiences are removed, see Hobart 2002.

37 Wessing 1996; Fish n.d.; Dituduh nyantet 2006; Isu santet 2006; Korban 2006; Sakit perut 2006; Lagi 2006a, 2006b . 


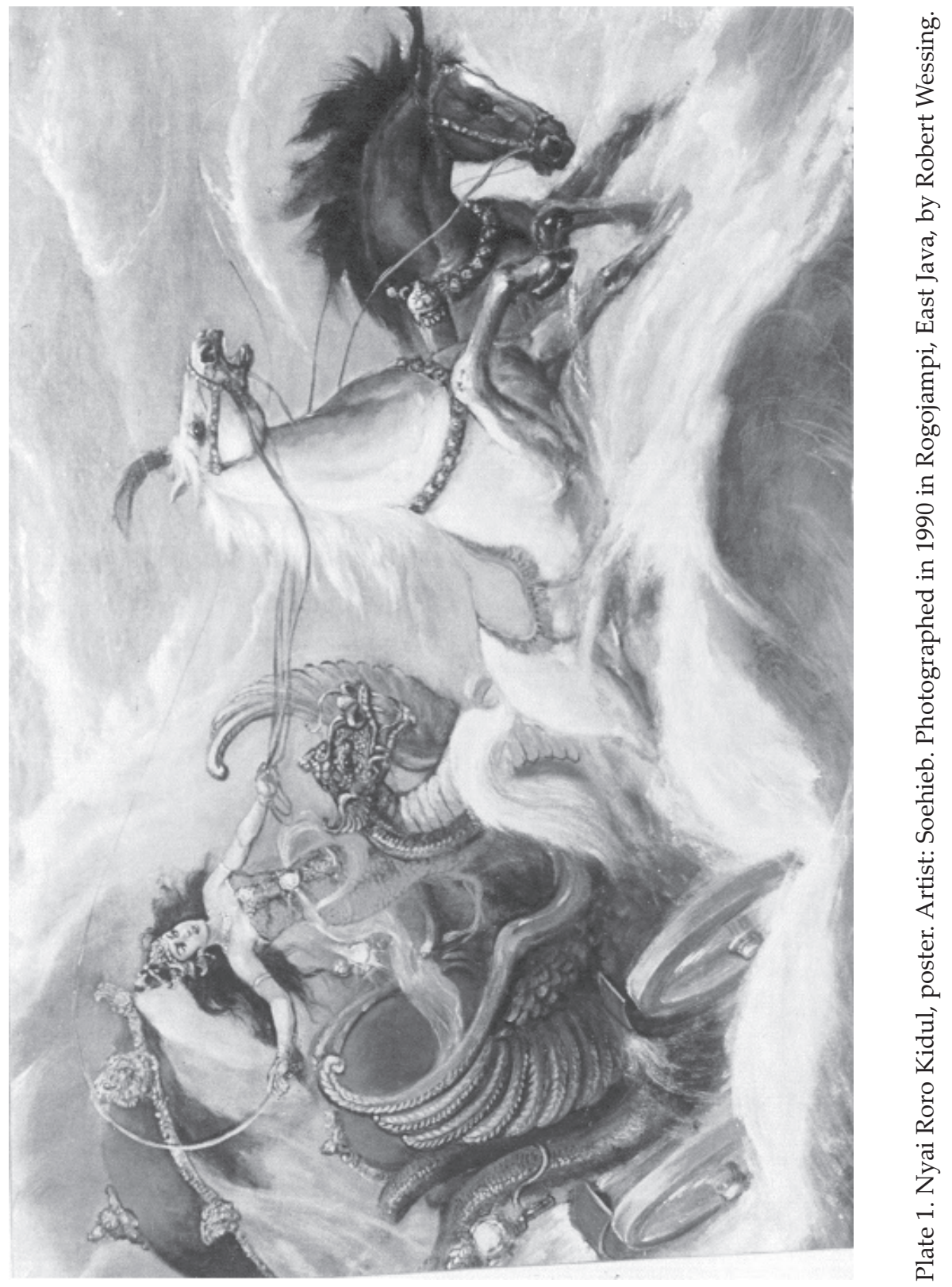




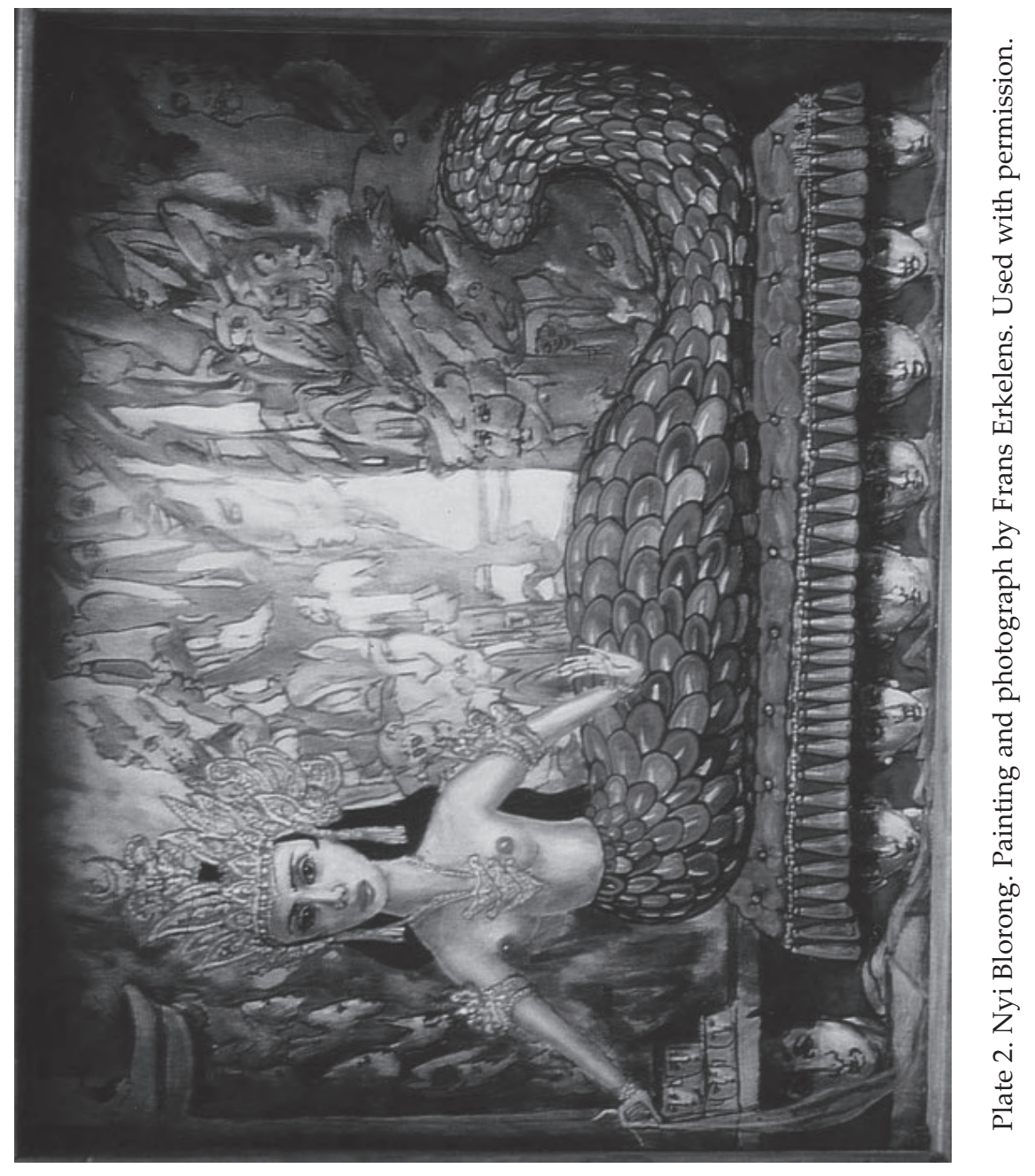




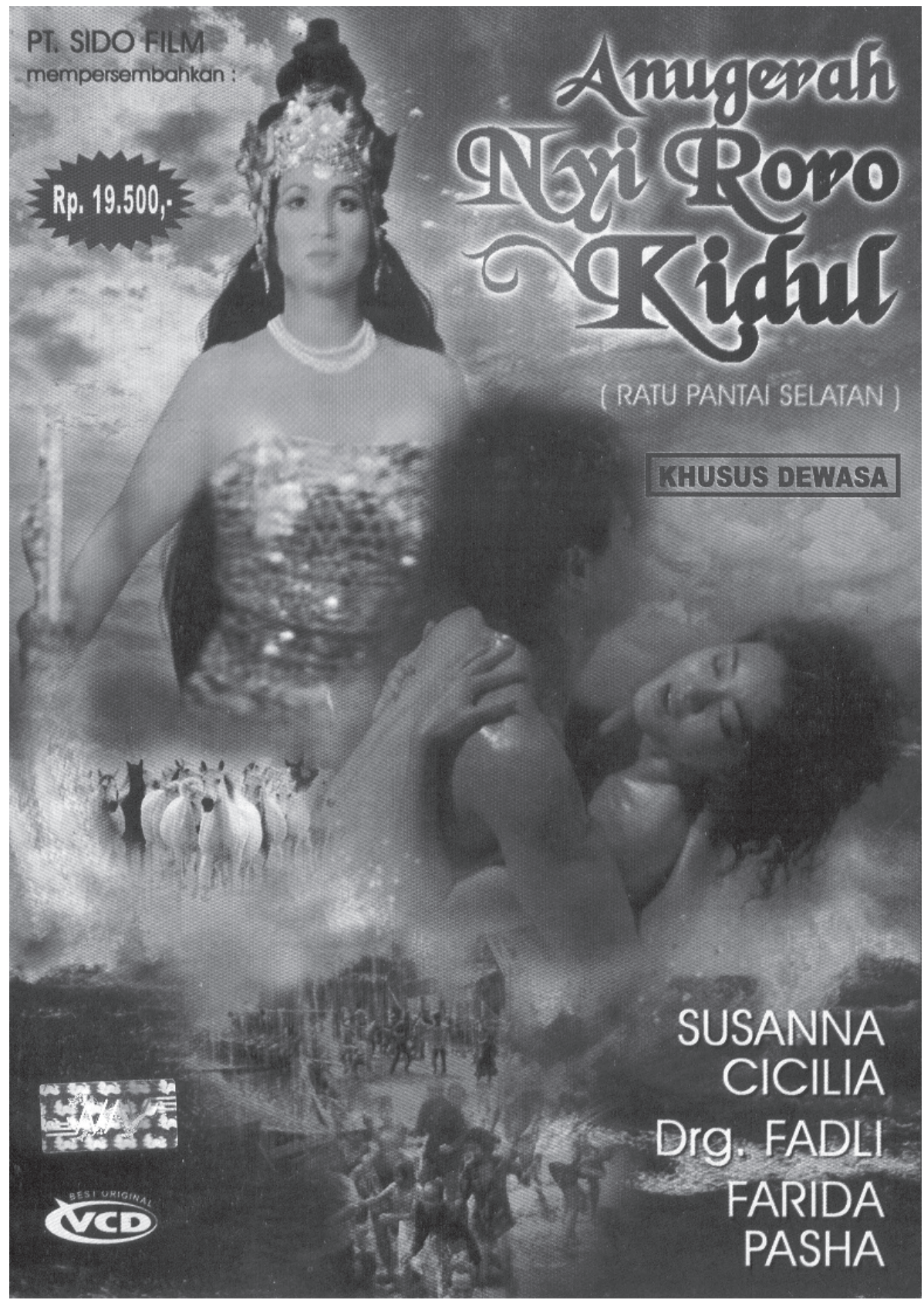

Plate 3. Nyai Roro Kidul. VCD cover for Anugerah Nyi Roro Kidul. 


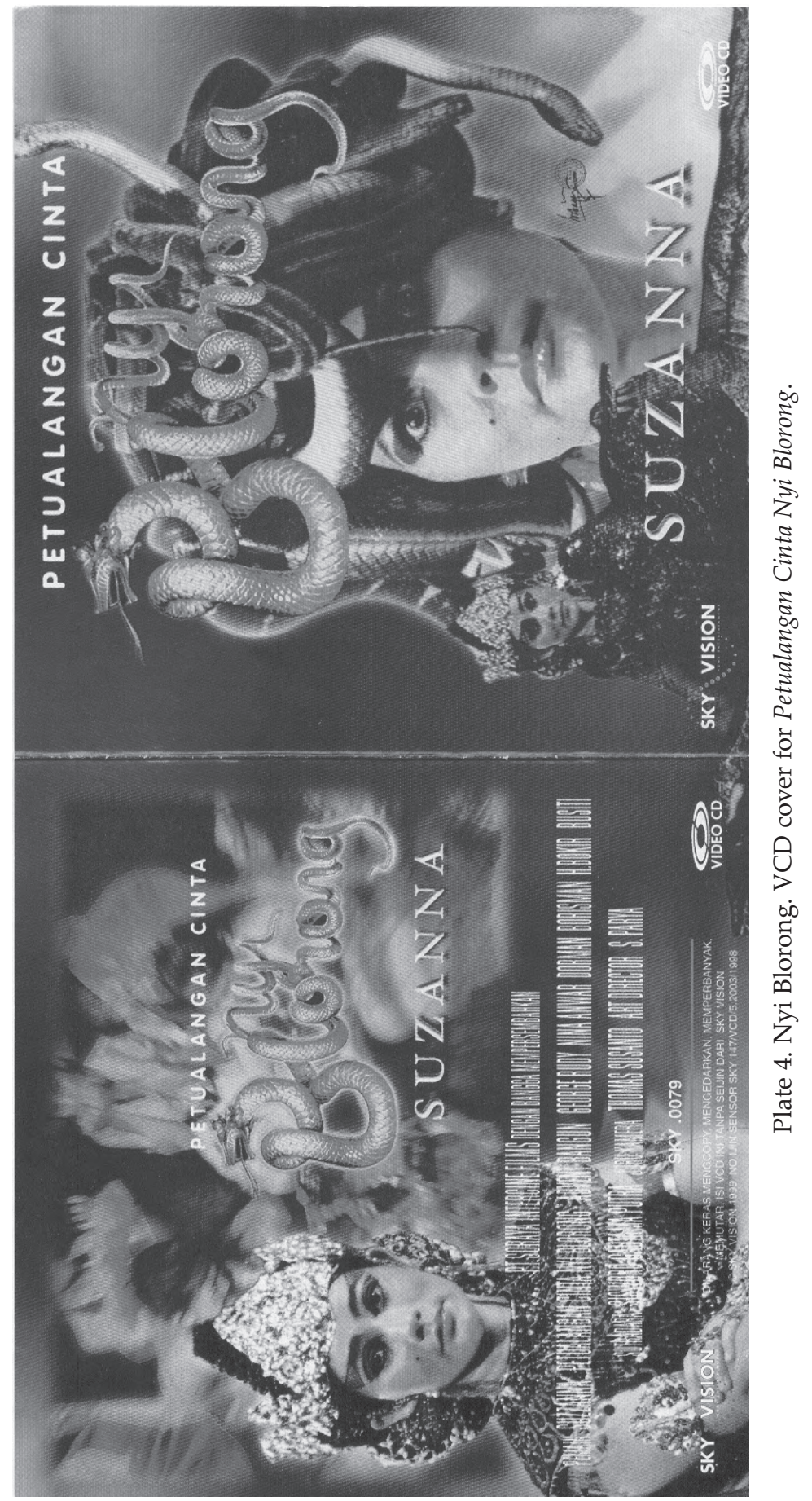


observed earlier, in the made-for-television films Nyai Roro Kidul and Mustika Nyi Roro Kidul she mainly acts as a deus ex machina who helps foil the forces of disorder. In only two films, Kutukan Nyai Roro Kidul (1979) and Pembalasan Ratu Laut Selatan (1999), neither of which star Suzzanna, is she portrayed as a purely evil creature, a spirit out only for her own interests. In the latter film this is because she is trying to regain an object that was stolen from her.

Even though, as Schlehe (1998:240) notes, Nyi Blorong is 'tempting, awe inspiring, violent, bloodthirsty and [...] in the final analysis [...] just', she is portrayed negatively in only one film, the post-Soeharto television drama Nyi Blorong; Titisan Ratu Nagandini, in which she eats human flesh and kills newborn babies to counter a rival. However, in another post-Soeharto television film, Misteri dua alam: Anak titipan Nyi Blorong, she acts as the hero's fairy godmother (she is actually his real mother) and supports him when he battles the forces of crime and deception. In most films about her she lectures people on the dire consequences of their desire for instant wealth. In Petualangan cinta Nyi Blorong she chides the fake sorcerer Bokir for his phony act, and his gullible clients for believing in such nonsense, while in Kisah cinta Nyi Blorong she advises the petitioner not to ask for wealth. The moral message, Schlehe (1998:240) observes, is that those who go to the spirits for wealth, rather than earning it through their own labours, will receive their just rewards. This balanced portrayal of our two personages notwithstanding, in many films magic and sorcery are very negatively valued. ${ }^{38}$

A moralizing tone is also adopted by the films' religious figures, even though they do not always only appear at the end of the film to save the day, as Film-film horor (2003:71) claims. Though this is often true, in Kutukan Nyai Roro Kidul the Islamic teacher arrives rather early in the film and immediately makes his mark: using only one hand, he prevents a woman from being molested - in his other hand he holds his bag. He then prevents the leading lady from being lynched, teaches the village to pray and leave sin behind, marries the leading lady, releases her from the snake in her vulva, and goes off with her, probably to spread the word of God somewhere else. Similarly, in Santet; Ilmu pelebur nyawa, the Islamic teacher calls on God and subdues the spirit that has been upsetting order in the village. Mentioning government slogans like Pancasila ${ }^{39}$ and the law, and admonishing people not to take the law into their own hands (jangan main hakim sendiri), he takes the hand of the female lead and walks off with her. Even those in league with the forces of disorder can be redeemed, as long as they bertobat (repent) (Nyi Blorong: Titisan Ratu Nagandini): in the presence of a religious leader, sorcerers and

38 For example Kafir (Satanic) and the Misteri Ilahi series shown on the television channel TPI.

39 Pancasila is the Indonesian state philosophy that includes a belief in God and justice for all. In Malam Satu Suro the sundel bolong, when finally returning to her own ghostly realm, admonishes her son to grow up to be of service to his religion, people and country. 
their ilk are powerless (Gibson 2000:42).

The religious leaders in the films, then, tend to preach: as one informant said, 'Dakwa masuk $T V^{\prime}$ (Islamic missionizing has come to television). Interestingly, however, none of my informants mentioned that belief in the Queen or Nyi Blorong was forbidden by religion. Indeed, on the television show Pemburu hantu (Ghost hunters), the Islamic authority who is one of the show hosts 'confirms the existence of supernatural beings and explains that this is also acknowledged in the Quran'.40

To summarize, the films under discussion here begin by referring to notable and sometimes exciting elements of the myths as these are known from the literature and folklore, like the colour green, snakes, and a proclivity for promiscuous sexual activity, and in this way they gain a measure of authenticity. ${ }^{41}$ As Bruner (2002:94) writes, the possible worlds created by narrative fiction are extrapolated from the known world. Of course, this is not something idiosyncratically Indonesian, but rather inherent in how stories work. Moving on from there, the filmmaker is free to add additional elements, for example by referring to other mythologies, especially where this adds spice to the tale he is telling. Such remixing, while permanent once the film is made, can vary from film to film since, of course, it is not a uniform process but is at least partially determined by the filmmaker's purpose in telling this particular tale. The filmmaker is relatively free here because each telling of the tale is in principle a new one and thus a reconstruction, constrained by the context of its presentation. This then allows new elements to be incorporated into the story and new interpretations to be given to old story lines. ${ }^{42}$

The addition of comic-relief figures like Bokir compensates for the loss of anchorage in a particular locale, because through these figures the film's locale becomes any village, its problems common to many. Thus the stories have a greater freedom to develop, unrestricted by particular local parameters, while at the same time, as discussions with viewers showed, being subject to testing against the local truths held by the individual viewers (Fish n.d.). The addition of the religious leader places the tale in a wider, national perspective, addressing supra-local questions about the nature of modernity, the place and reality of mythological figures, and the parameters of being an Indonesian Muslim in the present time. The variety of answers given by the films to these questions show that this is an ongoing debate in Indonesia and that the question of how to define an 'Indonesian Muslim' is

\footnotetext{
40 Arps and Van Heeren 2006. In any case, the Queen is said to have embraced the Muslim faith (Woodward 1989:261, note 27; Ricklefs 1974:203).

41 The emphasis on sex in advertisements for the films may also increase their commercial potential.

42 Filmmakers are not alone in doing this, of course. In his 1990 novel Perang the celebrated author Putu Wijaya integrates elements like modern weapons, mobile phones, and computers into the Bharata Yuda War. The book's back cover calls it a contemporary wayang story.
} 
far from resolved. ${ }^{43}$ Many voices are trying to be heard, each claiming to tell the authentic or preferable version of the national tale and each heard by an audience with varying perceptions of what is being said, even if the speaker, be he preacher, politician or filmmaker, has a particular ideal audience in mind (Hobart 1999:266; Wessing 1978b).

In all this, television plays a peculiar role in that, while on the one hand it is part of 'national media space' (Sen and Hill 2000:199) that plays an important role in creating 'national imaginaries' (Ginsburg, Abu-Lughod and Larkin 2000:11; Anderson 1991), its messages, and increasingly those of films on $\mathrm{VCD},{ }^{44}$ upon entering people's living rooms, become, as Fish (n.d.) has shown, part of local reality with which they then start interacting. This is, of course, far truer of television than of films shown in local theatres, whose audiences are assemblies of relative strangers who do not necessarily all have the same reference points (Hatley 1988:20). ${ }^{45}$ Yet even there, local perceptions are not absent, as is illustrated by moviegoers' reluctance to wear green to the theatre where a Nyi Blorong film was playing. Therefore, rather than considering television and VCD discs as intrusive and external, it is perhaps better to see them as yet another local (or localized) source of information and authority on supra-local matters, while in the supernatural area they are part of a continuum between local spirits and those made familiar by the media. Indeed, as Randal Baier (personal communication 2005) observed, electronic mediation seems to give tales greater authority or truth, just like publishing a version of a tale tends to raise its status to that of the 'correct' version (Sweeney 1980:7; cf. Goody 1996:670), which tends to disempower traditional storytellers (Kitley 1999:138), leading to a decline in storytelling at home (AW 1991).

43 See for instance the issues addressed by former president Abdurrahman Wahid (Jangan samakan 2006:12) and by the Muslim scholar M. Dawam Raharjo (Novriantoni 2006:10). See also the debate on the proposed pornography laws and the reaction by for example the Front Pembela Islam (Front for the Defense of Islam) to the stand taken by the popular singer/dancer Inul (http:// www.indonesiamatters.com/297/human-trash-dangdut-singers/, last accessed 24-7-2006). At issue here is the debate whether Islam in Indonesia should be considered as a cultural aspect of life (for instance the Indonesianization of Islam) or whether it should become an institutional part of society (Wahid 2006; Kolaborasi Islam 2007). By extension this also includes the place of 'folk Islam' and the place of entities like the Queen and Nyi Blorong in the belief system. Although it has recently intensified in post-Soeharto Indonesia, this debate is actually not new and has been carried on since at least colonial times (Baso 2006:400-3).

44 In 1990 Jember, East Java, had a three-theatre Cineplex and a rather run-down movie house showing 'porno' (occasionally slightly risqué) films. In 2005, however, the Cineplex had succumbed to the combined pressures of the monetary crisis and the advent of VCD and DVD modes of viewing (Tiket supermurah 2006). The 'porno' house continues to show its usual fare.

45 I am reminded of a small group of anthropologists from the University of Illinois (Urbana) that, stopping in London after fieldwork in Africa, decided to go see Stanley Kubrick's then recently released film 2001. At the point in the film where the computer HAL states that he was assembled in 'Urbana, Illinois' the anthropologists as a group burst out laughing, to the amazement of the rest of the London audience that, of course, did not have this place as an immediate reference point. 
Viewing television or VCDs is generally done in the context of a group whose religious, political and other preferences are known, if not always agreed with (Ruby 2000:188). Even here, the presence of a respected narrator can influence how messages are received, especially in situations where television or films are watched communally. This can be a way for neighbours to socialize (Hamilton 2002:158), but it can also be a forum in which an opinion leader can elucidate his or her views. ${ }^{46}$ In this way 'media space' interdigitates with 'local space'.

As television and VCD viewing become more common in individual homes, the immediate influence of local opinion leaders gives way to that of the most respected member of the household and, of course, of the views that are expressed in the film or programme. These, in turn, reflect the interaction of numerous parameters, including those of the film and television industries and the restrictions to which these are subject, and, of course, local sensibilities, which they sometimes get wrong. ${ }^{47}$ Through the media, therefore, local beliefs and forms of expression become subject to influences from outside agencies, including the state, the Broadcasting Commission, ${ }^{48}$ and the religious establishment. The way stories are presented places the viewer in what Steele (2005:148) calls an 'interpretive framework' that shapes the meaning of the tale and attempts to lead the viewer to certain preferred conclusions. Given the nature of television viewing, during which people frequently do all kinds of other things, from answering the telephone to doing homework, these attempts are often less than successful as 'viewers simply attribute to a picture what they already know [...] regardless of what the producer intended' (Ruby 2000:189, 184). Personal predilections or predispositions can, of course, further influence this process, either positively or negatively.

\section{Conclusion}

As can be concluded from our discussion about the role of narrative, 'talked together' communities are emergent, contingent, contested, ideological and political, and reflect a variety of competing interests (Niles 1999:143). In daily life,

46 These views may be publicly accepted, but away from the opinion leader they may later be rejected (Ruby 2000:188-9).

47 For example the 1991 airing in Surabaya of the Canadian cooking programme Wok with Yan, featuring the preparation of pork at the start of the fasting month of Ramadan (Kitley 1992:100). The restricting agents need not be local either, as Salman Rushdie (Satanic verses) and Theo van Gogh (Submission) found out to their respective inconvenience.

48 In March 2006 the Komisi Penyiaran Indonesia put thirteen television stations on notice for screening items that were loaded with sex, violence and mysticism (KPI tertibkan televisi 2006:1). In December 2006 they reported eight stations to the police for the same offence (Pramudito 2006:1, 7). 
this ongoing local discussion is the reference context for understanding both the realities and the mythologies that people encounter. This is the context in which matters like the meaning of the Queen, but also of religious and thus social and political matters, are clarified and understood (Sen and Hill 2000:124). Here too, the Queen quickly becomes linked to local spirits (Wessing 2006b:52-6). Myths and other stories reflect a specific kind of truth (Fischer 1987:6), being models of the world (Bruner 2002:25) and also models for our continued construction of it. Given the importance of these questions, we could therefore be said to be speaking here of a contest for mythical space, since 'media space' presents us with a new niche in which new interpretations of both myths and religion are possible. Even sacred texts can become 'arenas for contestation' (Abshar-Abdallah 2003:133), in which attributed meaning might depend more on the nature of the audience than on the intentions of the communicator (Caldarola 1990:3-4, cited in Ruby 2000:183; Wessing 1978b). If in the past the interpretation of these mythologies was tied to specific locales (Wessing 2006b:49-50), their move into 'media space' has loosened them from these old ties which, as happens to spirits and gods generally, has created for them the possibility of a wider appeal but which also subjects them, again like religion generally, to the possibility of a much greater range of interpretations or manipulation.

As Sean Williams reminded me ${ }^{49}$ the visual aspect of film plays an important role here, its impact being quite different from an oral rendering of the tale. She suggests that life performance necessarily involves considerable audience interaction and makes possible immediate feedback (which is also shown by Hobart's data (2002:380)) while linking the tale with local spirit entities. The mediated versions do the reverse and remove the tales from the local and bring them into a national arena. Thus, what the tale loses in local intimacy it gains in scope and impact. ${ }^{50}$

For the Indonesian state, ${ }^{51}$ one of films' preoccupations is the maintenance of social order - Sen and Hill (2000:43, 145) speak of their 'moralizing tone' (see also Heider 1994:170). Thus the Sundel bolong opposes the gang that victimized her in life (as does the kuntilanak in Kuntilanak; Harum sundal malam), and the religious leaders in many of the films join in the fight against disruptive forces like were-creatures and criminals - the latter depicted as crude (kasar) and emotional in contrast with the imperturbable calm exuded by the religious leader. In this way the films attempt to socialize their teenage viewers into becoming proper members of the state, the first plank of whose national philosophy (Pancasila) is a belief in one God. 'The guru agama [reli-

49 Email, 21-8-2006.

50 Yet the intimacy of a local telling should not be underestimated, as anyone who has heard such tales told by flickering lamplight or at a campfire can testify.

51 Sen and Hill write about Soeharto's regime, but the concern has not changed since then, even though the newspapers these days seem to reflect the existence a higher degree of disorder than they did under Soeharto. 
gious teacher] figure teaches us not to be afraid of devils', a male informant in his early twenties from a religiously rather relaxed household said, 'It shows that reciting verses from the Quran can help overcome them'. The same person, however, would walk away or change the channel when the religious messages were laid on too thick for his taste. As Heider (1991:109) points out, 'films must make money by telling entertaining stories', and when they cease to entertain, people will turn away. My informant's younger siblings, however, an eleven-year-old girl and a fifteen-year-old boy, tended to stay glued to the screen, the boy even reciting religious phrases along with the television preachers during the call to prayer. ${ }^{52}$

While the mythological figures we have been looking at used to be primarily matters of local concern, since their film debuts they have progressively become caught up in a larger discussion about Islam and its position vis-à-vis these beliefs, a discussion in which their portrayal varies from absolute evil, to neutral, to benign and advisory. ${ }^{53}$ Being mythological figures, they have little if any say in these portrayals, though those asking their permission to do the films do not, perhaps, see them as totally powerless. But, with or without permission, the film's director is relatively free to develop the narrative as he and the interests behind the film wish. As we have seen, these portrayals have little to do with the role that these figures played locally, such as ensuring that fishermen get good catches or legitimizing the state. The only one relatively true to her original form is Nyi Blorong, but she too is made to denigrate the petitioners who come to her and, in some of the television films, has even become a benign figure. ${ }^{54}$ Given their much wider audience with its varied individual local spirit concerns, the Queen and Nyi Blorong continue to be mediated by local spirit icons, although these are perhaps ones that they might in the past not have had to face. They are also mediated by the influence of local and supra-local (for instance televised) religious figures. Both mediations make a single valuation of them difficult. As Heider (1991:10,

52 During a return visit five months later, however, all three had drastically reduced their television viewing, devoting their time instead to sports, dolls, schoolwork, and in the case of the elder boy to a new-found job.

53 Condren (1989:132), discussing serpent symbolism in a Western, Christian context, notes that people's understanding of the snake moved successively from one of contextually 'good' or 'evil' (depending on people's actions) to there being both good and evil snakes, and finally to the fully evil serpent being crushed by Mary's heel. From their depiction in the films we are discussing, we might conclude that in Java the mythology has moved into the 'both good and evil ones' stage, at least in different films, and that even though in some films uztadz try to crush the mythological figures, this has not completely succeeded.

54 Her name is now even used by a Malaysian 'emo-violence' band that put out an album entitled Suffocated by passion, clearly playing on Nyi Blorong's reputation for freely engaging in sexual activity. Websites featuring this band can be found by typing 'Nyi Blorong band Malaysia' into a search engine. These sites tend to disappear, however. On 9 August 2006 their album was discussed on http://www.attackfanzine.net/class.htm. 
1994:165, 168) writes, films are helping shape Indonesian national culture, which includes rewriting those aspects of past belief that no longer fit in with Indonesia's new social realities (Niles 1999:83). Yet there are many aspects of that culture that are still matters for contention, including the position of these myths and religion in the nation's system of values as well as the system of values itself.

\section{List of films}

Ajian Ratu Laut Kidul, 1991, starring Suzzanna and Cliff Sangra. Sky Vision VCD 0066, http://mitglied.lycos.de/uzumaki/reviews/ajian.htm, last accessed 21 July 2006.

Anita (Ular Betina), ca. 2000, starring Enny Beatrice and Advent Bangun. Virgo Compact Disc, no website found.

Anugerah Nyi Roro Kidul, 2003 (?), starring Susanna Cicilia, Drg. Fadli, and Farida Pasha. PT. Sido Film VCD, no website found.

Bangunnya Nyai Roro Kidul, 1985, starring Suzzanna, George Rudy, Dorman Borsiman, Bokir, Bu Siti and others. PT. Soraya Intercine Films, VCD, no website found.

Bayi Misteri, 2003, Starring Merry Putriany, Icha Alicia, Achul Wiraperwata and Lela Anggraeni. Virgo Putra Films VCD, http://www.odiva.com/b2c/odiva_order_movie_info.asp?product_id=20076, last accessed 21 July 2006.

Buaya Putih, 1982, starring Yati Octavia and Sisca Widowati. PT. Pan Asiatic Films, http://www.imdb.com/title/tt0343495/, last accessed 21 July 2006.

Kafir (Satanic), 2002, starring Suwijo Tejo and Meriam Bellina. PT. Kharisma Starvision Plus, VCD, http://gbcode.tdctrade.com/gb/tpwebapp.tdctrade.com/fair/filmart/03/ firms_detail.asp?years=2003\&movieID=32\&country_code=\&genre=HOR, last accessed 8 September 2006.

Kisah Cinta Nyi Blorong, 1999, starring Joyce Erna, Kiki Fatmala and Harry Capri. Kapi Film VCD, no website found.

Kuntilanak: Harum Sundal Malam, 2004, starring Maya Karin, Azri Iskandar and Rosyam Nor. Pesona Films VCD, http://www.imdb.com/title/tt0371890/, last accessed 19 July 2006.

Kutukan Nyai Roro Kidul, 1979, starring Yannie Wulandari, Yusuf Pangerean and Wati Siregar. Studio unclear, no website found.

Malam Satu Suro, 1988, starring Suzzanna, Fendy Pradana, Dorman Borisman, and H. Bokir. PT. Soraya Intercine Films, http://mitglied.lycos.de/uzumaki/reviews/malamsatusuro.htm, last accessed 19 July 2006.

Mistik (Leak), 1981, starring Ilona Agathe B. and Itje Trisnawati. PT. Navirindo Duta Audio Visual, http://www.dvdmaniacs.net/Reviews/M-P/mystics_in_bali.html, last accessed 21 July 2006.

Nyi Blorong (Putri Nyi Roro Kidul, 1982, starring Suzzanna, Barry Prima, Ratno Timoer and George Rudy. Studio unclear, http://mitglied.lycos.de/uzumaki/specials/suzzanna.htm, last accessed 21 July 2006.

Pembalasan Ratu Laut Selatan, 1999 (?), starring Yurike Prastika and Barbara Constable. PT. Soraya Intercine Films VCD, no website found. 
Petualangan Cinta Nyi Blorong, starring Suzzanna, Advent Bangun, George Budi, Nina Anwar, Dorman Borisman, H. Bokir and Bu Siti. Sky Vision VCD 0079, http:// us.imdb.com/title/tt0471871/, last accessed 17 July 2006.

Ratu Buaya Putih, 1988, starring Suzzanna, Jefry Daniel, Chris Salam, Bokir, Dorman Borisman and others. PT. Soraya Intercine Films VCD, http://mitglied.lycos.de/uzumaki/reviews/whitecrocodilequeen.htm, last accessed 21 July 2006.

Santet: Ilmu Pelebur Nyawa, 1988, starring Suzzanna, Jeffry Daniel, and Joice Erna. PT. Soraya Intercine Films VCD, http://mitglied.lycos.de/uzumaki/reviews/santet1. htm, last accessed 21 July 2006.

Santet 2: Wanita Harimau, 1989, starring Suzzanna, Jeffry Daniel, Rina Hassim, H. Bokir and others. PT. Soraya Intercine Films, http://mitglied.lycos.de/uzumaki/reviews/ santet2.htm, last accessed 21 July 2006.

Siluman Manusia Harimau (Misteri Gunung Merapi), 2000, starring Farida Pasha, Marcellino and Raivaldo. PT. Genta Buana Pitaloka, no website found.

Sundel Bolong, 1981, starring Suzzanna, Bambang Siswanto, Ktut Suwite and others. PT. Rapi Films, http://mitglied.lycos.de/uzumaki/reviews/sundelbolong.htm, last accessed 19 July 2006.

Tumbal Darah Perempuan, 2003 (?), starring Fitri Kurnia, Cheppy Chandra and Yunita David. Virgo Putra Films, no website found.

\title{
Television films
}

Legenda Ular Putih, started on the TPI television channel in March 2006.

Misteri Dua Alam: Anak Titipan Nyi Blorong, Indosiar 27 March 2006.

Misteri Dua Alam: Mustika Nyi Roro Kidul, Indosiar 17 April 2006

Nyai Roro Kidul, viewed in 2004

Nyi Blorong: Titisan Ratu Nagandini, TPI (?) 1 April 2006

\section{References}

\author{
Abshar-Abdallah, Ulil \\ 2003 'Menimbang Islam pribumi', Tashwirul Afkar 14:129-35. \\ Air liur \\ 1982 'Air liur di sebuah gua', Tempo 12-16:75-6. \\ Anderson, Benedict R. O'G.
}

1990 'Cartoons and monuments; The evolution of political communication under the New Order', in: Benedict R. O'G. Anderson, Language and power; Exploring political cultures in Indonesia, pp. 152-93. Ithaca, NY: Cornell University Press. [Wilder House Series in Politics, History and Culture.]

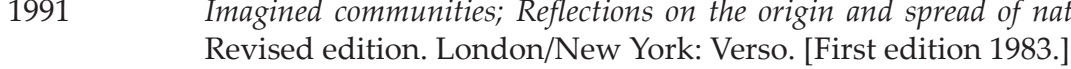

Arps, Bernard and Katinka van Heeren

'Ghosthunting and vulgar news; Popular realities on recent Indonesian television', in: Henk Schulte Nordholt and Ireen Hoogenboom (eds), Indonesian transitions, pp. 289-325. Yogyakarta: Pustaka Pelajar. 
Austin, J.L.

1975

How to do things with words. Second edition. Cambridge, Mass.: Harvard University Press. [William James Lectures 1955.] [First edition 1962.]

AW

1991

'Prof. Dr. Suripan; Televisi masuk desa, dongeng tersingkir', Surya 5241:2.

Bamar Eska

[1992] Sihir, santet dan tenung; Ditinjau dari agama Islam dan Kristen. Surabaya:

Baso, Ahmad

Bintang Remaja.

2006

NU Studies; Pergolakan pemikiran antara fundamentalisme Islam dan fundaBeatty, Andrew mentalisme liberal. Jakarta: Erlangga.

1996 'Adam and Eve and Vishnu; Syncretism in the Javanese slametan', The Journal of the Royal Anthropological Institute 2-2:271-88.

Brandes, J.L.A.

1920 Pararaton (Ken Arok), of Het boek der koningen van Tumapel en van Majapahit. Tweede druk. 's-Gravenhage: Nijhoff, Batavia: Albrecht. [Verhandelingen van het Bataviaasch Genootschap van Kunsten en Wetenschappen Bruner, Jerome

62.] [First edition 1896.]

2002 Making stories; Law, literature, life. Cambridge, Mass.: Harvard University Press.

Caldarola, Victor J.

$1990 \quad$ Reception as cultural experience; Visual mass media and reception practices in outer Indonesia. PhD dissertation, University of Pennsylvania, Philadel-

Condren, Mary phia.

1989 The serpent and the goddess; Women, religion, and power in Celtic Ireland. San Francisco: Harper and Row.

Diam-diam

1989 'Diam-diam', Editor 2-41:61.

Dituduh nyantet

2006 'Dituduh nyantet, sugik sumpah pocong', Jawa Pos (Radar Jember), 25 February, p. 31.

Emigh, John

1996 Masked performance; The play of self and other in ritual and theatre. Philadelphia: University of Pennsylvania Press.

Endicott, Kirk Michael

1970 An analysis of Malay magic. Oxford: Clarendon Press. [Oxford Mono-

Eringa, F.S. graphs on Social Anthropology.]

1984

Soendaas-Nederlands woordenboek. Mede met gebruikmaking van eerder door R.A. Kern bijeengebrachte gegevens. Dordrecht/Cinnaminson: Fo-

Film-film horor ris Publications. [KITLV.]

2003

'Menjenguk film-film horor Indonesia; Dari Babi Ngepet hingga Jelang-

kung', Tempo 31-51:69-83. 
Fish, Sheila

n.d. 'Jurig talk; (Re)telling stories, re-membering television'. [Manuscript.] Fisher, Walter R.

1987 Human communication as narration; Toward a philosophy of reason, value, and action. Columbia, SC: University of South Carolina Press. [Studies in Rhetoric/Communication.]

Foley, Kathy

1992 'The medium and the message; Sintren, trance performance of Cirebon', in: Kathy Foley (ed.), Essays on Southeast Asian performing arts; Local manifestations and cross-cultural implications, pp. 23-53. Berkeley, Calif.: Centers for South and Southeast Asian Studies, University of California. Forth, Gregory

[Center for Southeast Asia Studies, Occasional Paper 18.]

1998 Beneath the volcano; Religion, cosmology and spirit classification among the Gibson, Thomas

Nage of eastern Indonesia. Leiden: KITLV Press. [Verhandelingen 177.]

2000 'Islam and the spirit cults in New Order Indonesia; Global flows vs. local knowledge' Indonesia 69:41-70.

Ginsburg, Faye D., Lila Abu-Lughod and Brian Larkin

2002 'Introduction', in: Faye D. Ginsburg, Lila Abu-Lughod and Brian Larkin (eds), Media worlds, pp. 1-36. Berkeley, Calif.: University of California Press.

Goody, J.

1996

'A kernel of doubt', Journal of the Royal Anthropological Institute 2-4:66781.

Hamilton, Annette

2002 'The national picture; Thai media and cultural identity', in: Faye D. Ginsburg, Lila Abu-Lughod and Brian Larkin (eds), Media worlds, pp. 152-70. Berkeley, Calif.: University of California Press.

Har

n.d. Nyai Roro Kidul; Cerita dari Jawa. Bandung: Citra Budaya. [Seri Cerita Rakyat.]

Harnaeni HHs.

1985 Kekasih Nyi loro Kidul; Cerita dari Jawa Barat. Bandung: Citra Budaya. [Seri Cerita Rakyat.]

n.d. Kurban Penguasa Laut Selatan; Cerita dari Jawa Barat. Bandung: Citra BuHatley, Barbara daya. [Seri Cerita Rakyat.]

1988 'Texts and contents; The Roro Mendut folk legend on stage and screen', in: Krishna Sen (ed.), Histories and Stories. Cinema in New Order Indonesia, pp. 14-24. Clayton, Vic.: Monash University. [AIA-CSEAS Winter LecHeadley, Stephen C. ture Series, 1987.]

2004 Durga's mosque; Cosmology, conversion and community in Central Javanese Islam. Singapore: Institute of Southeast Asian Studies.

Heider, Karl G.

1991 Indonesian cinema; National culture on screen. Honolulu: University of Hawai'i Press. 
1994 'National cinema, national culture; The Indonesian case', in: Wimal Dissanayake (ed.), Colonialism and nationalism in Asian cinema, pp. 162-73. Bloomington, Ind.: Indiana University Press.

Hien, H.A. van

1912 De Javaansche geestenwereld en de betrekking, die tusschen de geesten en de zinnelijke wereld bestaat, verduidelijkt door petangan's or tellingen, bij de Javanen en Soendaneezen in gebruik; Deel 1: De geschiedenis der godsdiensten en Hobart, Mark der tijdrekenkunde op Java. Vijfde en verbeterde druk. Bandoeng: Fortuna.

1999 'The end of the world news; Articulating television in Bali', in: Raechelle Rubinstein and Linda H. Connor (eds), Staying local in the global village; Bali in the twentieth century, pp. 265-89. Honolulu: University of Hawai'i Press.

2002 'Live or dead; Televising theatre in Bali', in: Faye D. Ginsburg, Lila AbuLughod and Brian Larkin (eds), Media Worlds, pp. 370-82. Berkeley, Calif.: University of California Press.

Isu santet

2006

'Isu santet resahkan Karangrejo', Jawa Pos (Radar Banyuwangi), 20 March, p. 39.

Jangan samakan

2006 'Jangan samakan Islam dengan Arab', Jawa Pos, 7 April, p. 12. Jordaan, Roy E.

1984 'The mystery of Nyai Lara Kidul, goddess of the Southern Ocean', Archipel 28:99-116.

Kitley, Philip

1992 'Tahun bertambah, zaman Bertambah; Television and its audiences in Indonesia', Review of Indonesian and Malaysian Affairs 26-1:71-109.

1999 'Pancasila in the minor key; TVRI's Si Unyil models the child', Indonesia 68:129-52.

Knappert, Jan

1977 Myths and legends of Indonesia. Singapore: Heinemann Educational Kolaborasi Islam

Books. [Writing in Asia Series.]

2007 'Ahmad Gaus A.F. kolaborasi Islam dengan budaya lokal', Jawa Pos, 19 January, p. 10.

Korban

2006

'Korban diduga punya ilmu santet', Jawa Pos (Radar Jember), 12 May, p. 26 ,

KPI tertibkan televisi

2006 'KPI tertibkan 13 televisi; 89 Kasus pelanggaran terkuak', Surya 20-108:1, 11.

Kreemer, J.

1879

'Blorong of de geldgodin der Javanen', Mededeelingen van wege het Nederlandsche Zendelinggenootschap 23:1-12.

Lagi

2006 a

Lagi, warga minta sumpah pocong. Jawa Pos (Radar Jember), 4 March, p. 31

2006 b Lagi, warga minta sumpah pocong. Jawa Pos (Radar Jember), 18 March, p. 31. 
Legenda

1988 'Legenda, fakta sejarah, atau bohong-bohongan; Nyi Rara Kidul kini Lévi-Strauss, Claude usianya 510 tahun', Minggu Pagi 40-51:1.

1970 The raw and the cooked. Translated from the French by John and Doreen Weightman. New York: Harper Torchbooks. [Originally published as Le cru et le cuit, Paris: Plon, 1964.]

Meijboom-Italiaander, Jos.

$1924 \quad J a v a a n s c h e$ sagen, mythen en legenden. Zutphen: Thieme.

Niles, John D.

1999 Homo narrans; The poetics and anthropology of oral literature. Philadelphia:

Nourse, Jennifer W.

University of Pennsylvania Press.

$1999 \quad$ Conceiving spirits; Birth rituals and contested identities among the Lauje of Indonesia. Washington, DC: Smithsonian Institution Press. [Smithsonian

Novriantoni

2006

Nyai Roro Kidul

1991 “"Nyai Roro Kidul” Sosok Rekaan Senopati', Intisari 29-340:123-36.

O'Flaherty, Wendy Doniger

1988 Other peoples' myths; The cave of echoes. New York: Macmillan.

Olthof, W.L. (translator)

1987 Babad Tanah Jawi; Javaanse rijkskroniek. Tweede herziene druk; verzorgd en ingeleid door J.J. Ras. Dordrecht/Cinnaminson: Foris. [KITLV, Indo-

Pokok E tokoh nesische Herdrukken.] [First edition 1941.]

1989 'Pokok \& tokoh', Tempo 19-18:38.

Pramudito

2006 'Dianggap banyak muatan seks dan berbau mistis', Surya 21-37:1, 7.

Prawirasuganda, A.

$1964 \quad$ Upatjara adat di Pasundan. Bandung: Sumur Bandung.

Purbatjaraka

1962

‘Njai Lara Kidul, 1 \& 2', Penelitian Sedjarah 3-5:2-24, 3-6:17-23.

Putu Wijaya

1990 Perang. Jakarta: Pustaka Utama Grafiti.

Ricklefs, M.C.

1974 Jogjakarta under Sultan Mangkubumi 1749-1792; A history of the division of Java. London: Oxford University Press. [London Oriental Series 30.]

Rosidi, Ajip

1977 Si Kabayan dan beberapa dongeng Sunda lainnya. Jakarta: Gunung Agung. Rozaki, Abdur

2004 Menabur kharisma menuai kuasa; Kiprah kiai dan balter sebagai rezim klembar

Ruby, Jay di Madura. Yogyakarta: Pustaka Marwa.

2000

Picturing culture; Explorations of film $\mathcal{E}$ anthropology. Chicago: University of Chicago Press. 
Rully NH

n.d. Ratu Laut Selatan. N.p.: n.n.

Sabariyanto, Dirgo

1981 Babad Demak. Vol. 2. Jakarta: Proyek Penerbitan Buku Sastra Indonesia dan Daerah, Departemen Pendidikan dan Kebudayaan.

Sakit perut

2006 'Sakit perut, dikira kena santet', Jawa Pos (Radar Banyuwangi), 18 February, pp. 37,43 .

Schlehe, Judith

1991 'Versionen einer Wasserwelt; Die Geisterkönigin im javanischen Südmeer', in: Brigitta Hauser-Schäublin (ed.), Ethnologische Frauenforschung;

1998 Ansätze, Methoden, Resultate, pp. 193-211. Berlin: Reimer.

Sears, Laurie J.

Die Meereskönigin des Südens, Ratu Kidul; Geisterpolitik im javanischen Alltag. Berlin: Reimer.

1996 Shadows of empire; Colonial discourse and Javanese tales. Durham/London:

Sell, Hans Joachim

Duke University Press.

1955 Der schlimme Tod bei den Völkern Indonesiens. 's-Gravenhage: Mouton.

Sen, Krishna

1988 'Introduction', in: Krishna Sen (ed.), Histories and stories; Cinema in New Order Indonesia, p. 1. Clayton, Vic.: Monash University. [AIA-CSEAS Winter Lecture Series, 1987.]

Sen, Krishna and David T. Hill

2000 Media, culture and politics in Indonesia. Melbourne: Oxford University Press.

Skeat, Walter William

1972 Malay magic, being an introduction to the folklore and popular religion of the Malay Peninsula. With a preface by Charles Otto Blagden. New York: Spitulnik, Debra Blom. [First edition 1900.]

1993 'Anthropology and mass media', in: William H. Durkin (ed.), Annual Review of Anthropology 22, pp. 293-315. Palo Alto: Annual Reviews.

Spyer, Patricia

2002 Fire Without Smoke and Other Phantoms of Ambon's Violence: Media Effects, Agency, and the Work of Imagination. Rede uitgesproken bij de aanvaarding van het ambt van hoogleraar in de Culturele Antropologie en Sociologie van het huidige Indonesië aan de Universiteit Leiden op vrijdag 29 november 2002.

Sri Sultan

1988 Sri Sultan; Hari-hari Hamengku Buwono IX; Sebuah presentasi majalah Tem-

Steele, Janet po. Jakarta: Grafiti.

$2005 \quad$ Wars within; The story of Tempo, an independent magazine in Soeharto's IndoSubiyanto Hr. (ed.) nesia. Jakarta: Equinox, Singapore: Institute of Southeast Asian Studies.

n.d.

Misteri Nyai Lara Kidul. Solo: Mayasari. 
Sweeney, Amin

1980 Authors and audiences in traditional Malay literature. Berkeley, Calif.: Center for South and Southeast Asia Studies, University of California. [Monograph Series 20.]

Terada, Alice M.

1994 The magic crocodile and other folktales from Indonesia. Illustrated by Charlene K. Smoyer. Honolulu: University of Hawai'i Press.

Tiket supermurah

2006 Tiket supermurah, selalu berharap belas kasihan penonton', Jawa Pos

Turner, Victor (Radar Banyuwangi), 29 March, pp. 36-7.

1981 'Social dramas and stories about them', in: W.J.T. Mitchell (ed.), On narTuti Indra Malaon rative, pp. 137-64. Chicago/London: University of Chicago Press.

1988 'In theatre and film; Some personal notes', in: Krishna Sen (ed.), Histories and stories; Cinema in New Order Indonesia, pp. 10-3. Clayton, Vic.: Monash University. [AIA-CSEAS Winter Lecture Series, 1987.]

TVRI Yogyakarta

1991 'Nyai Ratu Kidul, materi Gatra Kencana TVRI Yogyakarta', Surya 5228:5.

Uchrowi, Zaim, Riza Sofyat and I. Made Suarjana

1988 'Sejumlah pertemuan dengan Nyai Roro Kidul', Tempo 18-29:49-54.

Wachtel, Paul Spencer

1977 'Fire mountain', Silver Kris (November-December):18-23.

Wahid, Abdurrahman

2006 Islamku Islam anda Islam kita; Agama masyarakat negara demokrasi. Jakarta:

Wessing, Robert Wahid Institute.

1978a Cosmology and social behavior in a West Javanese settlement. Athens, Ohio: Ohio University Center for International Studies, Southeast Asia Program. [Papers in International Studies, Southeast Asia Series 47.]

$1978 b$ 'The place of symbols in human interaction', in: Demitri B. Shimkin, Sol Tax and John W. Morrison (eds), Anthropology for the future, pp. 171-80. Urbana: Department of Anthropology, University of Illinois. [Research Report 4.]

1986 The soul of ambiguity; The tiger in Southeast Asia. DeKalb, IL: Center for Southeast Asian Studies, Northern Illinois University. [Monograph Series on Southeast Asia, Special Report 24.]

1988 'Spirits of the earth and spirits of the water; Chthonic forces in the mountains of West Java', Asian Folklore Studies 47:43-61.

1996 'Rumours of sorcery at an Indonesian university', Journal of Southeast Asian Studies 27-2:261-79.

1997a 'Nyai Roro Kidul in Puger; Local applications of a myth', Archipel 53:97120.

1997b 'A princess from Sunda; Some aspects of Nyai Roro Kidul', Asian Folklore Studies 56-2:317-53.

2001 'Telling the landscape; Place and meaning in Sunda (West Java)', Moussons 4:33-61. 
2002 'Shifting boundaries; Cosmological discourse in Java', in: Coen Holtzappel, Martin Sanders and Milan Titus (eds), Riding a tiger; Dilemmas of integration and decentralization in Indonesia, pp. 162-80. Amsterdam: Rozenberg.

2006a 'A community of spirits; People, ancestors and nature spirits in Java', Crossroads 18-1:11-111.

2006b 'Homo narrans in East Java; Regional myths and local concerns', Asian Folklore Studies 65-1:45-68.

Wilken, G.A.

1912 De verspreide geschriften van Prof. Dr. G.A. Wilken; Deel 3: Geschriften over animisme en daarmede verband houdende geloofsuitingen. Verzameld door Woodward, Mark R.

F.D.E. van Ossenbruggen. Semarang: Van Dorp.

1989

Islam in Java; Normative piety and mysticism in the Sultanate of Yogyakarta. Tucson, Ariz.: University of Arizona Press. [Monographs of the Associa-

Wormser, C.W. tion for Asian Studies 45.]

[1920] De heilige gong. Amsterdam: Van Campen

Zimmermann, Gerd R.

2003 Indonesien; Eine geographische Landeskunde. Nackenheim/Rh: Matahari. 